\title{
The Study of Philosophical Meaning of Batik and Kimono Motifs to Foster Collaborative Creative Industry
}

\author{
Kundharu Saddhono ${ }^{1}$, Sahid Teguh Widodo ${ }^{1}$, Muhammad Taufiq Al-Makmun ${ }^{1} \&$ Masakatsu Tozu $^{2}$ \\ ${ }^{1}$ Javanology Institute, Sebelas Maret University, Indonesia \\ ${ }^{2}$ Kokushikan University, Japan \\ Correspondence: Kundharu Saddhono, Javanology Institute, Sebelas Maret University, Indonesia. E-mail: \\ kundharu.uns@gmail.com
}

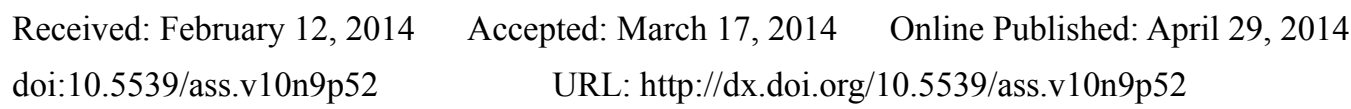

\begin{abstract}
It is interesting to conduct a comparative study of Javanese (Indonesia) and Japanese (Japan) culture especially in terms of traditional clothing of Javanese Batik and Japanese Kimono to formulate how a collaborative idea can be developed to foster a global creative clothing industry. This article aims at: (1) exploring a comparative study of Batik and Kimono by understanding their philosophical importance as cultural products; and (2) formulating a collaborative clothing of Batik-Kimono as a creative industry of global product to in the international forum today. The paper is based on a qualitative research employing purposive sampling and data triangulation technique by considering the socio-cultural context to interpret the qualitative importance of Batik-Kimono. The sources of data are collected from the informants - makers and designers, documents and social occurrences related to the creation of the cultural products. The findings show that both batik and kimono motifs have philosophical meaning representing their cultural identity for they have been rooted in each society of origin which own valuable virtue and excellence. Batik-Kimono, alternatively called as Kimba in this paper, is an asset that has a multi-purpose, not only in the context of preserving culture, but also in the field of creative industry. The combined motifs and designs of Kimba, therefore, reflect on the philosophical value by consistently paying attention to the aesthetics rooted in their cultures of origin to strongly appear as a new blended fashion in both countries and if not in the international forum. The model of development in this paper is presented as a four-season Kimba fashion.
\end{abstract}

Keywords: batik, kimono, creative industries, design, motif

\section{Introduction}

Batik and Kimono are closely related and alike in terms of function as fashion identity and content as they have deep cultural values; they further own future prospect as global assets in terms of creative industry as they have been recognized by both Indonesian and Japanese societies or even world-widely. Both Batik and Kimono have survived and fit into recent world's high fashion trend. In fact, they are easily found for being functionally used in both Indonesian and Japanese societies until today. Developing those cultural products collaboratively possibly find global reception. Formulating a new blended cultural product of Batik-Kimono fashion without leaving their valuable contents is the framework used in this paper. It, thus, will support the efforts to encourage international creative clothing industry by maintaining local ideas as the base. There are numerous efforts in rediscovering and developing cultural products to revitalize national identity rooted from local wisdom which is a strategic point in building national character and identity (Djoemena, 1990).

Batik is attached to Indonesian society as a national identity and recognized as Indonesia national outfits. Batik has been used, produced and found all over Indonesia even though mostly associated to Javanese society as its main origin. Batik characterizes Indonesia socio-culturally. According to Ayatrohaedi (1981), Indonesia has community group with particular life skills such as goldsmiths, interpreter, spokesperson, painter and batik painter. Koentjaraningrat (1985) underlines that artwork, particularly in Indonesia, i.e.; woven cloth, batik and textile is art branch rooted for centuries in high quality Indonesian culture, which is able to perform unique national identity.

To be part of Indonesian society since the eighth century, Batik is inherited from the forebears as a local genius 
and continues to have social acceptance by its society not only functionally as clothing but also deeper culturally to show distinguished identity. Batik was originally a traditional art that goes along with, settles in contemporary situation, and maintains traditions all at once (Honggopuro, 2002). According to Rizali (2011), decorative patterns and varieties of textile are combined by creation technique, background of reflection and local culture. Therefore, it enables traditional textile to be a national cultural identity. Visually, traditional textile form, batik in particular, not only represents beauty and aesthetics, but also moral norms and customs.

Batik as an Indonesian cultural product is durable and not static; over time, it communicates culturally within the development of the society. Batik motifs, for instance, continues to develop to win social acceptance. Batik had been part of cultural exchange of international trade in Indian Ocean between Indonesia and India; Maxwell emphasizes that the development of batik seems more closely connected to Indian chintz (Zilberg, 2012). Tracing Batik in the time of Islamic kingdom in Indonesia, Batik's decorative patterns and varieties had been strongly influenced by the woven's traditional art form in Indonesia, for example, the element of flower and geometric Arabic writing. This inspires to have further study of Indonesian traditional textile and batik which contains Islamic components (Kartiwa, 1987). Some decorative types of traditional Islamic batik's characteristics are symbolic forms that come from religious and cosmologic symbols (Bakhtiar, 1977). Thus, symbolic structure in the form of traditional decorative batik is a combination of symbolic constructive and evaluative symbol, cognitive symbol and expressive symbol (Triguna, 1997). Furthermore, Batik design innovations have also been carried out by using a touch of modern technology (Yin, 2009).

Similarly, Kimono is an iconic clothing culture owned by Japanese societies. Japanese has been recognized as a society with strong culture for their ability to maintain typical Japanese culture in terms of language, traditions, craft, fashion, etc. Kimono characterizes Japanese society with its typical pattern consisting of main gown and fabric belt-like known as obi.

Despite its declining usage, kimono survives as a part of Japanese clothes until today. Over a period the number of people who regularly wear the kimono has declined drastically (Chan Vili, 2007). It is often stated that the Meiji era saw finalization of the kimono as a single ensemble, perpetuating it as a national costume (Rybalko, 2013). However, kimono is still commonly used by Japanese in a formal international forum and traditional activities in Japan. In globalized word today, kimono is modified to fit with the newer era; fashion designers such as Issey Miyake have attempted to reinvent the kimono by using unconventional fabrics and rejuvenating the shape of the garment (Chan Vili, 2007).

However, the unique pattern -shape of kimono- survives the modern age. Like Batik, Kimono is colouring world's clothing culture today. It, indeed, enters global recognition by inspiring many world fashion designs. Chan Vili (2007) points famous brand Gucci to be ever launching a product inspired by kimono design. Its unique pattern and design can be developed if not made simpler to fit with the more modern society. In Japan itself through the rapid social change like the emergence of harajuku, kimono is still used by Japanese society as a high fashion outfit but limit to some occasions.

Examining the relationship of Indonesia and Japan, there has been cultural interaction on both Asian countries which enables the cultural product exchange. Japanese people love wearing Batik in summer time due to its thin fabric and simplicity. Batik is even worn in formal occasion by some Japanese people. The same reality is also found in some Indonesian communities that fits harajuku style with its exclusivity and comfort for self-expression. Observing traditional batik market in Solo, Klewer market, there are kimono-like clothes in batik motif to fulfill Indonesian need of modern fashion industry. The phenomenon shows that both societies have done such cultural shares in terms of fashion. Batik-Kimono is a cultural asset with multi-purpose in terms of not only culture, but also creative economy, such as fashion, design and craft (Tozu, 2011: iv).

\section{Methodology}

This study is a descriptive qualitative research which aims at interpreting the data to comprehend the philosophical meaning and cultural root of each Batik-Kimono through comparative studies. Therefore, it is to enable the research to comprehend various situations in the level of individual, group or particular social interaction (Lock, Spirduso \& Silverman, 1987). In this type of research, interpretation can arise from various social phenomena by comparing and classifying research object (Miles \& Huberman, 1992), the data then compressed through a data reduction process (Sutopo, 2002). The focus of qualitative research is informants' perception and experience, and their way in seeing their lives. Some reality should be understood and expressed on how each of them happens (Lincoln \& Guba, 1985; Frankel \& Wallen, 1990, Merriam, 1988).

The research applied purposive sampling technique based upon contexts. The sources of data are: (1) informants who are the makers or designers of Batik-Kimono, the industry, artists, cultural observers from both Indonesia 
and Japan, (2) documents which are documents related to Batik-Kimono such as research report, text book, resume and academic paper related to the kinds of Batik-Kimono's pattern and design, motif, form, meaning and function development, and (3) occurrence related to the creation of Batik-Kimono's pattern and design from which the data taken for the making process of Batik-Kimono's pattern and design both in Indonesia and Japan.

Triangulation technique is employed to test the validity of the data, which consist of sources (of data), method and theory. Triangulation of source means that the source is compared to find verity. A source is tested using other sources in a different context through; (1) comparing data of observation result and of interview, (2) comparing data of public observation and of an individual, (3) comparing data of constant data situational, (4) comparing data of individual argument and of public argument and (5) comparing data of interview and of documentary (Moleong, 2005). Principally, triangulation method is a test strategy of validity level based on comparison of data collecting technique and different source of data. The research applied data triangulation comprising data reduction, presentation and verification.

\section{Result and Discussion}

\subsection{Philosophical Meaning of Batik Motifs}

Batik is a craft possessing of high valuable. On October 2, 2009, UNESCO recognized Indonesian Batik as world cultural heritage and it was declared in Solo or Surakarta, Central Java which is considered to be the center of batik these days. The greatness of batik is presented by Musman (2011) and Doellah (2002) as a valuable heritage in Indonesia. The word 'batik' is derived from two words: amba, which means write and titik, which means dot. The process of making batik involves dipping process; in Indonesia canting is used as a tool to put malam - wax- on the part of a fabric desired to be colourless. It is a method of painting fabric such as cotton, silk, etc. by putting layers of wax which is made of yellow bee's wax mixed with paraffin and resin. In Egypt, batik technique was introduced in the $4^{\text {th }} \mathrm{BC}$ seen from the process of mummifying which was wax-layered and in pattern. Batik became familiarized in China during Tang Dynasty (618-907), in Japan and India during Nara Dynasty $(645-794)$ and in Nigeria at Yaruba tribe (Prasetyo, 2010).

Batik has been a part of Indonesia since the eighth century. Based on inscription sites, the experts believe that batik developed in Java has been known since the birth of Majapahit Kingdom in the $10-11^{\text {th }}$ century. Among many sources mentioning the history and origin of batik, Brandes (Dutch archaeologist) and Rouffaer state that Grinsing motif has been known in Kediri since $12^{\text {th }}$ century and it is also mentioned that Batik was earlier recognized in Indonesia in the eighth century in the time of Sriwijaya Kingdom in Sumatera island. It is also found in other source of Malayan literature that batik was presented in the $17^{\text {th }}$ century. In addition, Raffles (1817) explained that the development of batik art in Europe started in $19^{\text {th }}$ century when a Dutch merchant, Van Rijekevorsel handed over a piece of batik cloth he got from Java to a museum in Rotterdam. Since then, Javanese batik began to spread in Asia and Europe.

Over time, batik has developed by the advancement of technology and further, in many different areas of Indonesia, batik is found in variation in terms of motif. In its development, batik has been changing significantly. Nowadays, batik develops into batik tulis (written), batik cap (stamp), batik kombinasi (combination) and batik printing (printed). Until now, some experts say that batik consists of batik pesisir (coastal area) and batik keraton (palace). Batik keraton exposes mostly brown colour and grand colour (blue, yellow and white). Meanwhile, batik pesisir tends to be colourful. Every motif of batik keraton has a noble philosophical meaning that attaches to the concept of life and greatness with varied different functions.

Solonese batik, both batik tulis and cap, is famous for its traditional motifs. What makes it distinct from other is that it employs natural material (Prasetyo, 2010). In the piece of Sido Mukti and Sido Lurah motifs, it is found the entire copyrighted work of local taste. Every stain represents unique Javanese local taste. The development of Surakartan (Solonese) batik is inseparable from Islamic symbols. In the old time, Muslim merchants' leader used Batik as a means of economical struggle and proselytizing Islamic teaching. It is interesting to look at the time back in the beginning when batik was used only for royal family. In its development, batik was massively produced by merchants. Nowadays, batik turns to be people's craft in Surakarta.

Every batik motif encompasses philosophical meaning. Semen motif means spring or bud. Tree was considered as human's life symbol on earth. Therefore, as it is used as motif, it is expected that the wearer will be connected with God. Semen is a non-geometric pattern of drawing inspired by nature, like flower, leaf, mount and animal. Wulandari (2011) states that semen comes from water spring and generally, the decorative idea related to the earth and plants, four-leg animals, air, or cloud illustrated by cloud and flying animals and water. Semen Rama, one of semen motifs, is inspired by the story of King Ramawijaya who gives advice to Raden Gunawan Wibisana, King Dasamuka's brother. The advice is known as Hasta Brata, a leader's eight principle characteristics inspired 
by natural elements consisting of Indrabrata, Yamabrata, Suryabrata, Sasibrata, Bayubrata, Danababrata or Kuwerabrata, Barunabrata or Pasabrata and Agnibrata.

Ceplokan motif is a flower pattern which was developed during the reign of Sultan Agung Mataram, Mataram Kingdom, Surakarta in the $17-18^{\text {th }}$ century. It was used by both royal family and common people. Ceplokan Batik consists of two different boxes in one piece of cloth. One box is of paru-paru (lungs) motif and another one is filled with ukel (floral vector) motif. In Ceplokan Batik Sriwedari, the ukel motif is replaced by isen-isen parangan (sword-base motif as fillers), so there is a box of paru-paru and a box of other parangan motif. Sriwedari depicts a beautiful and luring garden that pleases and enchants every heart to cure boredom. Therefore, as it is worn, ceplokan batik Sriwedari is able to leave a soul to be serene and peaceful. It fits into married people of all classes of society.

Batik with "parang" and "lereng" motif is worn by Surakarta royal family as ageman luhur (noble attire). An opinion rising says that "parang" motif is associated to sharp weapon like parang (machete) or pedang (sword). However, other source states that the origin of "parang" motif comes from "pereng" which means steeply sloping riverbank or mountainside. It pictures diagonally and makes southern Java beaches slope like Paranggupito, Parangkusumo and Parangtritis, as basic figure. The meaning of batik is expected to be able to reach noble life and authority for public society.

Other batik motif developed is Batik Naga Gisikan. Naga is dragon, a giant snake. Gisikan means coastal area. In Javanese philosophy, these words mean a dragon enthroned as a symbol of peacekeeper. Batik Naga Gisikan is classified as semen motif with white primary colour and used by all classes of society, particularly by married people. Batik Sidamukti, Sidaluhur and Sidamulya are three similar motifs with different primary colour and meanings. Sidamukti uses ukel as its base. The wearer of this motif is expected to be favourable in the future by gaining wealth and high social position. While batik Sidaasih means a loving people.

Truntum motif is a picture of flowers motif with black primary colour. Truntum comes from Javanese word "tuntum" which means repetition or philosophically the entwining love of husband and wife. It also depicts two opposites in human's life like: happiness - sadness, light - darkness, husband - wife and day - night. Human will always be in the midst of "pepeteng" (darkness), "sakgebyaring lintang" (blinking stars) and "pepadhang" (enlightenment). Batik Wahyu Tumurun is usually used in watering ritual. For example, "mitoni" (the seventh month of pregnancy ceremony) ritual uses this batik motif with an expectation that the future-born baby will be strong, "kedunungan wahyu" (given a revelation) and away from temptation.

Batik Sekar Jagad is one of the most popular motifs. "Sekar Jagad" may be connoted to the world's bloom. It is assumed to be a "pinunjul" (better than others) which has noble character of "pakarti utami" (principle manner). Expectation lies within the motifs. Sekar Jagad is developed in the end of $18^{\text {th }}$ century in Surakarta and is used by all society classes casually and in traditional ceremonies.

Despite the above motifs that are basically derived from the motif found in Keraton -palace- represent the philosophical idea of royal family, outside of the palace are also found types of motif produced by merchants and consumed by common people. They, then, are categorized based on location like batik pesisir -coastal area, profession like batik petani-farmer, and social occurrence like batik larangan -prohibited- to name the use of royal motif outside of palace even though in some cases the motifs have been modified.

Nowadays, the motif is developed and used by common people in Java and Indonesia generally and even exported and worn globally without much consideration on the basic idea of the philosophical meaning. The motifs of batik larangan which literally means prohibited, for example, at the beginning were only possibly worn by royal family but now they are commonly found to be motifs of garments and clothing in the popular market accessible for anyone. Further, many today's garments use batik by combining two or more basic motifs in one piece to serve decorative function.

Even though batik motifs are now found in many different designs of fashion such as, shirt, skirt, jacket, souvenir, household ware, etc and no longer only attached to Indonesian traditional attire like sarong and selendang (sawl), the high value of the philosophical meaning of the motifs can still be traced to the design of the motifs. Batik motif, therefore, has chances to be empowered as a part of global product to be attached in today's fashion and industry. It, thus, is also strategic to maintain Indonesian cultural identity through its awareness of understanding that batik motifs own deep philosophical meaning representing its society of origin, Indonesia. The variety of batik motif talks the life cycle and hope in order that the wearers may feel that batik is not only functional but also meaningful. 


\subsection{Kimono Pattern and Philosophical Meaning of Kimono Motifs}

Kimono is Japanese national clothes. It is derived from word "ki" from "kiru" which means wear and "mono" which means thing. Literally, kimono is a thing to wear. According to Souga (1973), kimono is defined as a general term of anything that is worn on body. The Kodansha Bilingual Encyclopedia of Japan (1998) states that Kimono (literally: clothes) indicates the narrow sense of traditional Japanese cloth made of vertical panel fabric, tied with a sash (Obi), with rectangle sleeves and worn by men and women.

Noma (1974) argues that the grand beauty of a kimono lies in the artistic creation. It is said that Kimono is one of the most beautiful national clothes in the world. Kimono is an artwork revealing beauty and uniqueness of the wearer recognized through its design of pattern. The design of the pattern is easy to recognize by its typical open gown without button and worn by tiding it up with belt like fabric known as obi. Furthermore, the elegance and serenity is attached to Kimono through its natural colours and motifs which show a harmonious bond with nature. Noma adds that kimono with sakura or cherry blossom motif is worn in summertime, kimono with sea wave and red maple motif is worn in summertime and fall and kimono with snow and peach flower motif is worn in winter.

Recently, kimono is often worn by women in special occasion. Culturally, the pattern does not only show the beauty and unique in look but its varieties own different kinds of symbol of life. Furisode is kimono design worn by single women (Dalby, 2001). Its sleeves are long dangling to the ground. Men wear kimono in a wedding party, tea party and other formal occasions. Professional wrestlers are required to wear kimono outside the sumo arena (Sharnoff, 1993). Children wear kimono in attending the celebration of Shichi-Go-San. Besides, kimono is also worn by employees of tourism and service industry.

Tracing back the socio-cultural facts of Japan through its history, Kimono has developed through times. In the Edo age in Japan, there was no substantial difference between kimono for men and for women. It was then shown in the $17^{\text {th }}$ century; kimono for girls was decorated with a strong and brave colour. Young women wore kimono with bright colour. Kimono with even pattern and smooth colour was suitable for older women. The use of specific motif basically deals with the wearer's characteristics, particular emotion, season or chances. Symbolism in Kimono is mostly applied in celebration like wedding, festival and other special events.

Colour possesses connotation in metaphorical way and the development of culture. In the $6^{\text {th }}$ century Japan, colour, which has cosmological dimension, was considered being rooted from Chinese concept consisting of fire, water, soil, wood and metal and dealing with particular direction, season and wisdom. Moreover, there was a powerful poetic meaning in colour. For example, violet reflects a metaphor of an endless love and red shows glamour, youth spirit and bravery.

Kimono has philosophical meaning seen from the colour and ornamental pattern as motifs attached in it. Generally, kimono motif consists of abstract, animal, flower, plants and the combination of all motifs. Kimono with hexagonal motif similar to batik, indicates a prosperity and immortality. This motif is mostly used for newly born baby to expect that the baby will grow healthy. This pattern originally coming from west Asia like China and Korea, is named with "returning turtle" looking at the pattern which is turtle alike. Japanese believe that turtle brings luck and long life. Besides, hexagonal shaped flower and diamond motif symbolizes eternal togetherness in family and glory expectation in life.

Swastika is other kimono motif. In Hindu, it is one of the holiest symbols and rooted on historical background and cultural complex. Swastika is stated as a creation or belonging of a nation or of a particular belief. It is then spread to all over the world with some variations. A clockwise swastika represents a deed following the rules and habits in a society. A counter clockwise swastika symbolizes an action against the rules and practices in a society.

Seven jewels motif is a combination of four circles with its messed quarters to each other. The motif represents seven silvers in Buddhism referring to gold, silver, lapis lazuli, coral, agate, quartz and tridacnidae. Furthermore, it is similar to batik motif symbolizing a kinship which is constructed from differences. The differences tied together present beauty and peace. Japanese often uses this motif, which is classic and universal and called as "tasuki", in social event in public. After Heian age, the motif variation developed rapidly. There is flower, leafs and water drew in this pattern showing prosperity and welfare of the wearer. Diamond is as well appears in this pattern to represent wealth and welfare.

Kimono motifs in Japan are not only dominated by a combination of stripes and abstract symbol, but also by a full picture, like animals either the familiarized and rare ones. Some of the animals appearing as a motif in Japanese kimono are butterfly, rabbit, fish, deer, spider, sparrow, turtle, dragonfly, frog, etc. Deer is drawn its horn as its specific characters in motif in Japanese kimono because it has been a part of their life as the envoy of gods. Beside symbolizes eternity and longevity, it also symbolizes a wealth as the deer pictured is ridden by the 
gods. Moreover, deer reflects characters of calm, peace, beautiful and elegant. Another animal often used in Japanese kimono motif is rabbit. Rabbit symbolizes a significant intelligence and cleverness and persistence in life. Kimono with butterfly motif which is inspired from Chinese and well-known during Nara period, developed to be an independent motif by Heian period. In Japanese tradition, butterfly is a symbol of longevity for the wearer that most of them are young women.

One of bird motifs in Japanese kimono is a small bird living near the water ecosystem, like river, beach or lake. Japanese believe that the bird signifies a luck, virtue, longevity and humour because the bird sounds chiyo chiya booming, which means shaping a thousand generation. Sparrow is another bird motif. It is a wild bird seen in very road in all seasons. Sparrow motif is frequently combined with bamboo to represent togetherness and adaptive character. This motif is often used in social occasion, public ceremony, etc. Japanese also uses swallow as kimono motif. This motif is used in summertime as swallow migrates to Japan in the beginning of summer. The bird symbolizes luck, prosperity and faith in marriage. Crane which often appears in New Year celebration is also pictured in kimono to represent longevity and luck. Among many animals designed in origami, crane is the most popular.

To symbolize winning, freedom, self defense and survival success through life temptation, dragonfly appears in kimono. The motif is suitable for Japanese youth who seek for life direction when surviving against vulnerability and winning the life struggle. Kimono with dragonfly motif is mostly worn in the end of summer and the beginning of fall. Frog which its 27 species is seen in Japan is used as motif in kimono to symbolize luck. Influenced by Chinese, Japanese society consider spider as a symbol of hard working and endurance in taking challenges because the animal has eight legs to catch its prey easily. In some Japanese folklore, spider appears as human's good friend. As the west myth believes that spider has a bad connotation, Japanese combines it with plants, bugs and flowers.

The most popular and favoured motif in kimono is cherry blossom since Heian period. Cherry blossom reflects coolness, serenity and happiness. Yet, it also means a goodbye looking at the time the cherry blossom falls as the wind blows. The beauty of cherry blossom reflects spiritual and philosophical meaning of life. Japanese people sees cherry blossom representing opposites in life, such as happiness and sadness, life and death and glory and failure, all at once. It reminds people to be thankful in respecting and mourning.

Chrysanthemum, which originally comes from China and popular in Japan during Nara age (710-794 AD) portrays longevity, endurance, adaptive character, integrity and particularly a symbol of fall season. Chrysanthemum motif varies in Edo age. A wider range in using the flower as a kimono motif and an icon of imperial family happened during Meiji age. Currently, chrysanthemum is considered as the most exclusive motif and pride for the wearer as it, with its sixteen petals, is a symbol of Japanese empire.

Wisteria, an ancient and rare plant from Japan, has a beautiful combination of colour and shape. It is popular as kimono motif during the Heian age and developed into many artistic variations nowadays. Japanese consider descending fringe as luck and "golden ear" as harvesting time. Fall grass is also popular as kimono motif. It is pictured as seven fall plants; Hagi, Susuki, Kuzu, ominaeshi, Nadeshiko and Fujibakama. These plants symbolize sadness, loneliness and the expression of evanescent life. Generally, in fall, grass motif is combined with moon. People wear this motif in the time of mourn.

Pine often appears in Japanese kimono. It grows naturally and is valuable for practical purpose. Pine's special characteristic is its cone-shape. Green pine is a symbol of longevity, luck and diligence. Three fall plants; plum, pine and bamboo, which come together is considered as a symbol of luck. Pine and bamboo symbolize endurance as they stay evergreen even during winter. Plum is a new hope symbol. It is a longevity symbol as well, as it is efflorescent in its old age. Bamboo grows fast and tall. It is believed as powerful, nobility, purity, honesty and solemnity. Japanese consider bamboo as a good and holy plant. It is sometimes combined with snow, which is believed to bring luck.

To elicit, Kimono with its distinctive design of pattern has been known as Japanese identity and further inspiring the world fashion for its functional pattern as a cloth. Examining deeper, Kimono's motifs are not a random decorative setting of designs as they have been created to communicate culturally through philosophical meaning derived. Developing Kimono design to win global acceptance will be more strategic by considering its cultural and philosophical meaning possessed by both its patterns and motifs as the high value will still be attached.

\subsection{Developing Kimba as a Collaborative Creative Industry}

Batik and Kimono have big potentials to develop as a collaborative global product which possesses not only acceptable function and beauty in fashion but also represents the strength of cultural value speaking the identity 
of its origin. Cultural heritage is an education element that urges society to build sense of belonging to their culture. The effort to rediscover and revitalize local wisdom of inherent Batik-Kimono can be applied through education with the aim to support the re-emergence of the foundation of local cultural values as part of the effort in developing national identity and filtering various cultures in universal globalization (Agung, 2009). For both countries, Japan and Indonesia, the possible cultural collaboration brings economic value and cultural identity preservation. It is, further, strategic to promote their culture.

This article proposes that Kimba (kimono batik) can be developed by maintaining the beauty of kimono pattern and attaching the batik motifs in it. This collaborative product considers the strengths of each original product and puts respect on the philosophical meaning owned. Batik and Kimono have similarities in a way that motif attached in fashion does not only serve decorative function but symbol of life cycle; four-season Japan takes important influence in determining what motif may fit with while batik motifs represent stages of life and hopes. Furthermore, philosophically, both batik and kimono adopt natural environment and spiritual if not religious symbol as the inspiration. Differently, kimono has been recognized through its unique pattern and batik by its distinctive motifs. Combining the two cultural distinctive products by respecting their philosophical identity can be a model of development of such creative industry involving two or more cultural identities.

The following result is the model on how a collaborative Kimba can be conducted, a four-season Kimba. Indonesia has only two different kinds of season: rainy and dry season. Those seasons do not influence batik motifs. However, there are some batik motifs both the basic and filler motifs are able to be used to represent four seasons in Japan considering the way kimono adopts natural environment as the motifs attached in kimono. In line with the hot weather in summer, colours which give effect of brightness are like red, orange, and yellow. These are found in batik from coastal areas -batik pesisir. It can also be connected to Japan as society who consumes seafood; therefore, motif in batik pesisir commonly adopt ocean creatures.

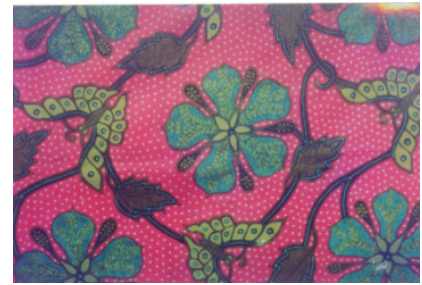

Figure 1. Radityo Puspita, a combination of inland and pesisir batik

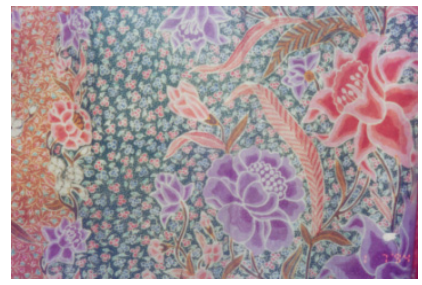

Figure 2. Buketan, batik pesisir

The condition of autumn in Japan is similar to Indonesian time in the late dry season entering rainy season in which leaves fall, and many trees left in leafless branches due to the daily hard blowing wind. Even though the following motifs do not represent literally the certain period of the season, the natural condition is found to be inspiration of some batik motif in the form of leafless vine plants of which colours are pale and less bright. It matches to attach in kimono in autumn theme.

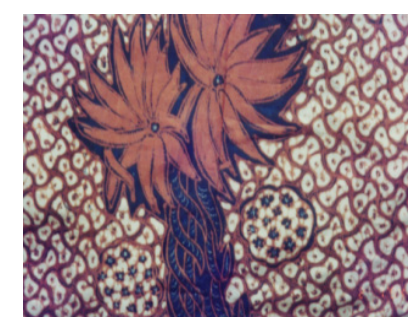

Figure 3. Kembangan motif, batik petani - farmer

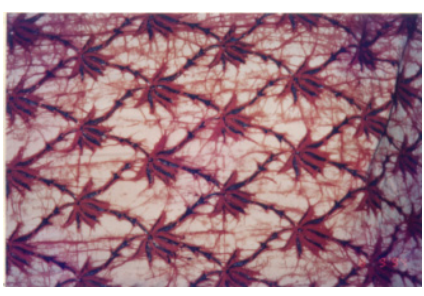

Figure 4. Wonogiren motif, batik petani

Spring time can be associated with batik motif of semen and alas-alasan. Semen is derived from the word semi which means growing while alas-alasan is derived from the word alas which means forest. Both are categorized as batik larangan. The non-geometrical designs are combination of the form of flora, fauna and entity. The idea of non-geomtrical is able to represent the spring time with fresh colour of the nature. 


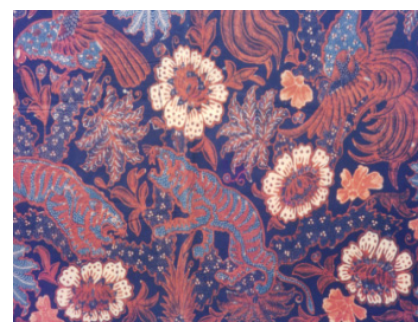

Figure 5. Alas-alasan, modern batik

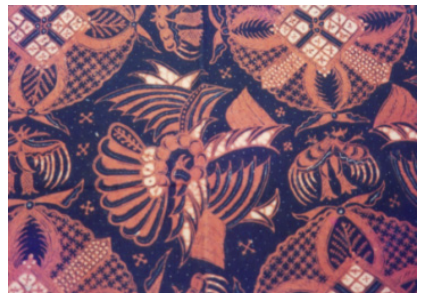

Figure 6. Ceplok motif, modern batik

Winter time can be represented through grey, white and blue colours. These are easily found in batik motif from Jogjakarta which is also called as batik bledak. Batik bledak commonly has white colour as the background setting. Some motifs found in batik pesisir may also match by considering its dominant colours.

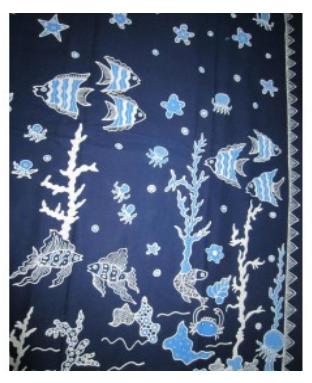

Figure 7. Fish motif, batik pesisir

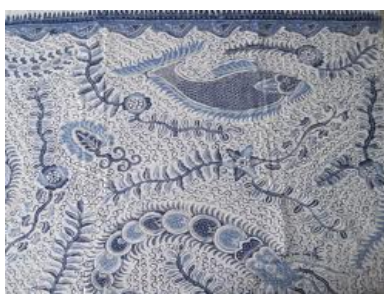

Figure 8. Sulur motif, batik pesisir

\section{Conclusion}

Based on the above analysis, kimono and batik have different yet related motif in terms of philosophical meaning coincided. The difference is significantly due to the prevailing culture and environment.

Batik motif in modern standard includes handmade standard motif, modified "larangan" batik and completely new motif. Modern batik can be easily found as household wares, additional room, souvenir and clothing. It is important to trace that the motifs coinciding high values of philosophical meaning. The basic motifs are symbolic motif, which contains particular intention related to life perspective and belief in the old days. Standard representation on basic motifs cannot be separated from the understanding of Old Javanese, Hindu and agricultural natural elements.

Kimono with its distinguished pattern of fashion uses motifs which have various philosophical meaning seen on colour and decorative motifs in respect to age, status, wealth and other aspects. Motif in kimono has high level of complexity with particular meaning and use. The use of particular motif deals with the wearer's status, emotional condition and existing season.

Kimba -Kimono-Batik- may appear as a strategic collaborative cultural product in terms of global creative industry by using kimono pattern with batik motif by keeping both philosophical meanings of the original products. Four-season Kimba can be a model of how developing a global product. High-valued cultural products of two different cultures are creolized in respect to the cultural identity where the original products belong to.

\section{Acknowledgements}

This research has been funded by grants of international research collaboration and scientific publication, Director General of Higher Education, Ministry of Education and Culture, Republic of Indonesian with contract No. $247 \mathrm{a} / \mathrm{UN} 27.11 / \mathrm{PN} / 2012$ and No. 165/UN27.11/PN/2013. The writers are thankful to the Asian Japan Research Center, Kokushikan University, Tokyo, Japan and Javanology Institute, LPPM-Sebelas Maret University. The writers also express gratitude to Theresia Widiastuti, textile expert from Sebelas Maret University, for her willingness to share documents as sources of data and her knowledge on textile industry.

\section{References}

Agung, L., \& Widiyastuti, E. (2009). Pengembangan model pembelajaran muatan lokal di sekolah menengah berbasis keunggulan budaya seni batik klasik Surakarta sebagai pelestarian warisan budaya dan menumbuhkan jiwa kewirausahaan. Research Report. Surakarta; LPPM Sebelas Maret University. 
Ayatrohaedi. (1981). Masyarakat sunda sebelum Islam. Majalah Ilmu-ilmu Sastra Indonesia, 9(1), 33-42.

Bakhtiar, L. (1977). Sufi expression of the mystiq quest. Singapura: Thomas and Hudson.

Chan Vili, Y. Y. F. (2007). The Evolution of Kimono Textiles in the Interests of Preserving Tradition. In K. Wells, \& J. Winder (Eds.), Ars Textrina International Textiles Conference: Textile Territories: Past, Present and Future, A Selection of Papers (pp. 32-34). Belfast: University of Ulster.

Dalby, L. C. (2001). Kimono, fashioning culture. Seattle, WA: University of Washington Press.

Djoemena, N. S. (1990). Ungkapan sehelai batik: Its mystery and meaning. Jakarta: Djambatan.

Doellah, S. (2002). Batik: pengaruh zaman dan lingkungan. Surakarta: Danarhadi.

Fraenkel, J. R., \& Wallen, N. E. (1990). How to design and evaluate research in education. New York: MacGraw-Hill Pub. Co.

Honggopuro, K. R. T. K. (2002). Bathik sebagai busana dalam tatanan dan tuntunan. Surakarta: Yayasan Peduli Karaton Surakarta Hadiningrat.

Kartiwa, S. (1987). Tenun ikat Indonesian ikats. Jakarta: Djambatan.

Kerlogue, F. (2005). Jambi batik: A Malay tradition? Indonesia and the Malay World, 33(96), 183-204. http://dx.doi.org/10.1080/13639810500283613

Koentjaraningrat. (1990). Metode-metode penelitian masyarakat. Jakarta: Gramedia.

Li, Y., Hu, C.-J., \& Yao, X. (2009). Innovative batik design with an interactive evolutionary art system. Journal of Computer Science and Technology, 24(6), 1035-1047. http://dx.doi.org/10.1007/s11390-009-9293-5

Lincoln, Y. S., \& Guba, E. G. (1985). Naturalistic inquiry. Beverly Hills, CA: Sage Publications.

Locke, L. F., Sprirduso, W. W., \& Silverman, S. J. (1987). Proposal that work: A guide for planning dissertation and grant proposals. Newbury Park, CA: Sage Publishing.

Merriam, S. B. (1988). Case study research in education: A qualitative approach. Newbury Park California: Josey-Bass Inc.

Miles, M., \& Huberman, A. M. (1992). Analisis data kualitatif: Buku sumber tentang metode-metode baru. Jakarta: UI Press.

Moleong, L. J. (2005). Metodologi penelitian kualitatif. Bandung: Remaja Rosdakarya.

Musman, A., \& Arini, A. B. (2011). Batik: Warisan adiluhung nusantara. Yogyakarta: G-Media.

Noma, S. (1974). Japanese costume and textile art. Tokyo: Heibonsha.

Prasetyo, A. (2010). Batik. karya agung warisan budaya dunia. Yogyakarta: Pura Pustaka.

Raffles, T. S. (1817). History of Java. London: John Murray.

Rizali, N. (2011). Tinjauan desain tekstil. Surakarta: Lembaga Pengembangan Pendidikan \& UNS Press.

Rybalko, S. (2013). Japanese Traditionnal Raiment in the Era of Modernization. Asian Journal of Social Science \& Humanities, 2(1), 260-266.

Sharnoff, L. (1993). Grand sumo, the living sport and tradition. NewYork: Weatherhill.

Souga, T. (1973). Nihon kakugo daijiten 6. Tokyo: Shogakkan

Sutopo, H. B. (2002). Metodologi penelitian kualitatif. Surakarta: UNS Press.

The Kodansha Bilingual Encyclopedia of Japan. (1998). The kodansha bilingual encyclopedia of Japan. Tokyo: Kodansha.

Tozu, M. (2011). The Meaning of Indonesian Batik as World Heritage. In M. Tozu, L. Romano, N. Yusoff, S. T. Widodo, \& K. Saddhono (Eds.), Reinventing the indigenous value of batik-kimono to strengthen the Indonesia-Japan relationship. Surakarta: Institut Javanologi, Pemkot Surakarta, Japan Foundation, dan Kokushikan University.

Triguna, I. B. G. Y. (1997). Mobilitas kelas, konflik dan penafsiran kembali simbolisme masyarakat bali. Disertation. Postgraduate Program of Padjadjaran University Bandung.

Wulandari, A. (2011). Batik nusantara: makna filosofis, cara pembuatan dan industri batik. Yogyakarta: Penerbit Andi. 
Zilberg, J. (2012). Textile History in Stone. Seloko, 1(2).

\section{Copyrights}

Copyright for this article is retained by the author(s), with first publication rights granted to the journal.

This is an open-access article distributed under the terms and conditions of the Creative Commons Attribution license (http://creativecommons.org/licenses/by/3.0/). 